\title{
Prolonged neuromuscular blockade by non-depolarizing neuromuscular blocking agents
}

\author{
Michiko Higashi ${ }^{1}$, Takahiro Tamura ${ }^{2}$ and Yushi U. Adachi ${ }^{2^{*}}$
}

To the Editor,

We read with great interest the case report by Moriwaki and Kayashima [1] in the journal. The authors described the patient demonstrating prolonged neuromuscular blockade even after administration of sugammadex considered as appropriate for reversal of rocuronium. After the surgery, the long-lasting residual blockade was antagonized by supplemental administration of neostigmine and atropine, and the patient's trachea was extubated without any complications. Although the course and the explanation were acceptable, we have several concerns for the case.

First, the authors administered neostigmine and atropine. The reversal temporally increased the train of four ratio; however, no one can predict the duration of prolonging blockade and the half time of neostigmine is approximately $1 \mathrm{~h}$. The patient showed the apparent residual blockade even after $163 \mathrm{~min}$ from the induction of anesthesia. More length of time might be required for the complete recovery [2]. Intensive care and careful observation would be appreciated.

Second, the authors emphasized the effect of magnesium and calcium-antagonists on acetylcholine release. The combination is well known for the treatment of cholinergic crisis in the area of toxicology [3]. The non-depolarizing neuromuscular blocking agents have presynaptic inhibitory effect on neuronal acetylcholine receptors [4]. The residual blockade might be so complicated and there was a room for discussion.

We previously reported the case of a patient developing recurarization after administration of sugammadex following a prolonged rocuronium infusion [5]. In the case, unexpected decrease of elimination of rocuronium by hypothermia might be a factor of the recurarization. The cause of unexpected prolongation and residual of neuromuscular blockade varies [6, 7]. Residual neuromuscular

\footnotetext{
* Correspondence: yuadachi@med.nagoya-u.ac.jp

${ }^{2}$ Department of Surgical Intensive Care Medicine, Nagoya University Hospital, 65 Tsurumai-cho, Showa-ku, Nagoya 4668550, Japan

Full list of author information is available at the end of the article
}

blockade absolutely could not be overlooked after anesthesia [8]. Anesthesiologists should pay more attention to prolonged neuromuscular blockade.

\author{
Acknowledgements \\ Not applicable. \\ Funding \\ No funding declared.
}

Availability of data and materials

Not applicable

\section{Authors' contributions}

$\mathrm{MH}$ read the manuscript and wrote the letter. $\Pi$ read the manuscript and revised the letter. YUA read the manuscript, conducted to write the letter, and revised the letter. All authors read and approved the final manuscript.

Ethics approval and consent to participate

Not applicable

Consent for publication

Not applicable

Competing interests

The authors declare that they have no competing interests.

\section{Publisher's Note}

Springer Nature remains neutral with regard to jurisdictional claims in published maps and institutional affiliations.

\section{Author details}

${ }^{1}$ Department of Emergency and Medical Intensive Care Medicine, Nagoya University Hospital, 65 Tsurumai-cho, Showa-ku, Nagoya 4668550, Japan. ${ }^{2}$ Department of Surgical Intensive Care Medicine, Nagoya University Hospital, 65 Tsurumai-cho, Showa-ku, Nagoya 4668550, Japan.

Received: 7 May 2019 Accepted: 10 May 2019

Published online: 19 May 2019
References
1. Moriwaki K, Kayashima K. Prolonged neuromuscular blockade and insufficient reversal after sugammadex administration in cesarean section under general anesthesia: a case report. JA Clin Rep. 2019;5:28.
2. Ezri T, Evron S, Petrov I, Schachter P, Berlovitz Y, Shimonov M. Residual Curarization and postoperative respiratory complications following laparoscopic sleeve gastrectomy. The effect of reversal agents: sugammadex vs. neostigmine. J Crit Care Med. 2015;1:61-7.
3. Brvar M, Chan MY, Dawson AH, Ribchester RR, Eddleston M. Magnesium sulfate and calcium channel blocking drugs as antidotes for acute 
organophosphorus insecticide poisoning - a systematic review and metaanalysis. Clin Toxicol. 2018;56:725-36.

4. Takagi S, Adachi YU, Saubermann AJ, Vizi ES. Presynaptic inhibitory effects of rocuronium and SZ1677 on [3H]acetylcholine release from the mouse hemidiaphragm preparation. Neurochem Int. 2002;40:655-9.

5. Murata T, Kubodera T, Ohbayashi M, Murase K, Adachi YU, Matsuda N. Recurarization after sugammadex following a prolonged rocuronium infusion for induced hypothermia. Can J Anesth. 2013;60:508-9.

6. Sung TY, You HJ, Cho CK, Choi HR, Kim YB, Shin YS, Yang HS. Effects of magnesium chloride on rocuronium-induced neuromuscular blockade and sugammadex reversal in an isolated rat phrenic nerve-hemidiaphragm preparation: an in-vitro study. Eur J Anaesthesiol. 2018;35:193-9.

7. Thevathasan T, Shih SL, Safavi KC, Berger DL, Burns SM, Grabitz SD, Glidden RS, Zafonte RD, Eikermann M, Schneider JC. Association between intraoperative non-depolarising neuromuscular blocking agent dose and 30-day readmission after abdominal surgery. Br J Anaesth. 2017;119:595605.

8. Esteves S. Can residual paralysis be avoided?: a critical appraisal of the use of sugammadex. Eur J Anaesthesiol. 2015;32:663-5.

\section{Submit your manuscript to a SpringerOpen ${ }^{\circ}$ journal and benefit from:}

- Convenient online submission

- Rigorous peer review

- Open access: articles freely available online

High visibility within the field

- Retaining the copyright to your article

Submit your next manuscript at $\boldsymbol{\nabla}$ springeropen.com 